Plant Tissue Cult. \& Biotech. 28(1): 57-68, 2018 (June)



\title{
Biochemical and Molecular Characterization of Bangladeshi Wheat Varieties for Bread-Making Quality
}

\author{
Sbatie Lama*, Muhammed Rezwan Kabir ${ }^{1}$ and Md. Abdullah \\ Yousuf Akhond ${ }^{1}$
}

Department of Biology, Molecular Cell Biology Unit, Lund University, Sölvegatan 35, 22362 Lund, Sweden

Key words: Bread-Making Quality, Bangladeshi Wheat varieties, HMW-GS

\begin{abstract}
Twenty-six wheat genotypes including 18 Bangladeshi varieties and 8 varieties /ines collected from different countries were evaluated for their breadmaking quality. Total grain protein content was measured using Kjeldahl method. Presence of the high molecular weight glutenin subunits (HMW-GS) and their corresponding genes were characterized through SDS-PAGE and PCR based methods. Total protein content of $53.85 \%$ of the genotypes ranged between 12 and $14 \%$ which is considered as a suitable range of protein for making bread. At the Glu-A1 locus, Ax2* alleles were found with a frequency of $84.62 \%$. At the Glu-B1 locus, 4 different alleles; Bx7, Bx7+By8, Bx7+By9 and Bx17+By18 were detected. At the Glu-D1 locus, PCR test result showed that $61.11 \%$ Bangladeshi wheat varieties contain Dx5+Dy10, regarded as the best allele for making bread. Four genotypes, Kalyansona, Sonora-64, Pavon-76 and BARI Gom 28, were found to have the highest quality score of 10. Among those, Kalyansona and BARI Gom 28 had the best HMW-GS combination of Ax2*, Bx17+By18, Dx5+Dy10 and Ax2*, Bx7+By8, Dx5+Dy10, respectively. This study will be important for specifying wheat genotypes for the food industry and further breeding for bread-making quality.
\end{abstract}

\section{Introduction}

Wheat (Triticum aestivum L.) is one of the most important cereal crops in the world. It occupies 17 per cent of the total cultivated land and is the staple food for 35 per cent of the world's population (International Development Research Centre 2010). In Bangladesh, wheat is the second most important cereal crop after rice (Hossain and Teixeira 2013). It is the most preferred crop for making

*Author for correspondence: <sbatie.lama@biol.lu.se>. ${ }^{1}$ Biotechnology Division, Bangladesh Agricultural Research Institute (BARI), Gazipur, Bangladesh. 
bread (Dewettinck et al. 2008). There are two types of wheat on the basis of endospermic texture, i.e. soft wheat and hard wheat. Hard wheat flours are suitable for making bread and soft wheat flours are suitable for making cookies and cakes (Dubcovsky et al. 1998).

Gluten, the main endosperm storage protein of wheat seeds is very important for determining the bread-making quality of flour. Compared to rye and barley, quality and concentration of gluten proteins is higher in wheat (Goesaert et al. 2005) making it the most common and suitable grain for baking bread. Gluten forms a continuous viscoelastic protein network when flour is mixed with water to form dough. Viscoelastic properties of gluten enable the wheat flour to be made into bread, cakes, biscuits and other food products. High molecular weight glutenin subunits (HMW-GS) is the most important group of gluten protein that determines the bread-making quality in wheat ( $T$. aestivum) (Malik 2009). Dough elasticity is considered to be very important property of wheat for making bread. It is mainly determined by the composition of HMWGS (Xu et al. 2008).

Generally, 3 - 5 HMW-GS alleles are expressed in each wheat cultivar. Allelic variations in HMW-GS and presence and absence of specific alleles play the critical role in determining bread-making quality. Presence of alleles Ax1, Ax2*, Bx17+By18, Bx14+By15 and Dy5+Dy10 in different combinations are considered as good for making quality breads. On the other hand, presence of null or Dx2+Dy12 showed negative impact on bread quality (Payne et al. 1987, Hamer et al. 1992, Gupta et al. 1996, Ahmad 2000).

It is generally assumed that Bangladeshi wheat varieties are not suitable for making bread. No information is available presently on the composition of HMW-GS in the Bangladeshi wheat varieties. Knowledge about the composition of HMW-GS is important for selecting varieties suitable for making good quality bread and breeding for improving wheat quality. Therefore, the present study was designed to identify HMW-GS of wheat varieties grown in Bangladesh along with some exotic genotypes in relation to the bread-making quality both at the protein and molecular levels using SDS-PAGE and PCR based techniques.

\section{Materials and Methods}

Twenty six wheat genotypes were selected for the study; 18 Bangladeshi wheat varieties: Kheri, Balaka, Ananda, Kanchan, Akbar, Barkat, Aghrani, Protiva, Sourav, Gaurav, Shatabdi, Sufi, Bijoy, Prodip, BARI Gom 25, BARI Gom 26, BARI Gom 27 and BARI Gom 28; two Indian varieties: Kalyansona and Sonalika; two varieties developed by CIMMYT (Mexico): Sonora- 64 and Pavon- 76; two British 
varieties: Mulika and Paragon; two Australian lines developed by CSIRO: Westonia 5907, Westonia 5924.

Total nitrogen content of the wheat materials were determined by Kjeldahl method and the total amount of protein was estimated by multiplying the total nitrogen values with the conversion factor for wheat endosperm 5.7 (Morel and Bar-L'Helgouac'H 2000).

Protein extraction and SDS-PAGE analyses were done following the method described in the MASWHEAT (Marker Assisted Selection in Wheat) of UC Davis University, USA (http://maswheat.ucdavis.edu). Proteins were extracted from 1-2 seeds of each wheat genotype. High molecular weight glutenin subunits were analysed by Sodium Dodecyl Sulphate Polyacrylamide Gel Electrophoresis (SDSPAGE) in $10 \%$ polyacrylamide gel $(\mathrm{T}=10 \%)$ with $1.28 \%$ cross-linker concentration $(\mathrm{C}=1.28 \%)$.

The electrophoresis was carried out in a Bio-Rad mini protein 3 system (BioRad, USA) having gel size $8.3-7.3 \mathrm{~cm}$. The samples were loaded at $25 \mu \mathrm{l} /$ ane. Electrophoretic separations were carried out at constant $200 \mathrm{~V}$ for 1.5 hours. Following electrophoresis, gels were stained in a solution of methanol $(400 \mathrm{ml})$, acetic acid $(100 \mathrm{ml})$, Coomassie Blue R $250(1 \mathrm{~g})$ and distilled water $(500 \mathrm{ml})$ for 16 hours followed by de-staining in tap water for $24 \mathrm{hrs}$ with occasional shaking and change of water. The protein bands were imaged through gel documentation system (Alpha Inotech, USA). A molecular weight marker (10-200 KDa) was used for comparison (Wide Range Protein Molecular Weight Unstained Marker, Cat \# BSM0661, Bio Basic Inc., Canada). The HMW-GSs individual or subunit pairs were used to predict the bread-making quality on the basis of the Glu-1 scoring system (Payne et al. 1987).

The 26 genotypes were grown in small plastic pots in the greenhouse. Young and tender leaves were harvested when they were 10 days old and $100 \mathrm{mg}$ sample from each was used for DNA extraction. Genomic DNA was isolated by following the protocol of Genomic DNA Mini Kit (Plant) (Geneaid, Version: 0424-13). Polymerase chain reaction (PCR) was carried out in a $20 \mu \mathrm{l}$ reaction volume containing $2 \mu \mathrm{l} 10 \times$ buffer $\left(\mathrm{MgCl}_{2}\right), 10 \mathrm{mM}$ dNTPs $(0.4 \mu \mathrm{l}), 5 \mathrm{U} / \mu \mathrm{l} \mathrm{Taq}$ DNA polymerase (Invitrogen) $(0.5 \mu \mathrm{l}), 5 \mathrm{pmol} / \mu \mathrm{l}$ forward primer $(2.0 \mu \mathrm{l}), 5$ pmol/ $\mu \mathrm{l}$ reverse primer $(2.0 \mu \mathrm{l}), 50 \mathrm{ng} / \mu \mathrm{l}$ DNA template $(2.0 \mu \mathrm{l})$ and $11.1 \mu \mathrm{l}$ water. Sequences of PCR primers and fragment sizes are shown in Table 1 . The PCR products were analyzed by electrophoresis in $1 \%$ agarose gel at $100 \mathrm{~V}$ for 1 $\mathrm{hr}$ and visualized over ultraviolet light using a gel documentation system (Alpha Innotech, USA). 
Table 1. PCR primers of the molecular markers used in the study.

\begin{tabular}{|c|c|c|c|c|}
\hline $\begin{array}{l}\text { Marker/ } \\
\text { gene }\end{array}$ & $\begin{array}{l}\text { Forward and reverse } \\
\text { primers }\left(5^{\prime}-3^{\prime}\right)\end{array}$ & Allele & $\begin{array}{l}\text { Fragment } \\
\text { size (bp) }\end{array}$ & References \\
\hline $\mathrm{A} \times 2^{*}$ & $\begin{array}{l}\text { F: ATGACTAAGCGGTTGGTTCTT } \\
\text { R: ACCTTGCTCCCCTTGTCTTT }\end{array}$ & Glu-Ax2* & 1319 & $\begin{array}{l}\text { Ma et al. } \\
\text { (2003) }\end{array}$ \\
\hline Ax1 & R: ACCTTGCTCCCCTTGTCCTG & & & \\
\hline Bx7 & $\begin{array}{l}\text { F: ATGGCTAAGCGCCTGGTCCT } \\
\text { R: TGCCTGGTCGACAATGCGTCGCTG }\end{array}$ & Glu-Bx7 & 2373 & $\begin{array}{l}\text { (Anderson } \\
\text { and Greene } \\
\text { 1989) }\end{array}$ \\
\hline $\begin{array}{l}\text { ZSBy8F5/ } \\
\text { R5 }\end{array}$ & $\begin{array}{l}\text { F:TTAGCGCTAAGTGCCGTCT } \\
\text { R:TTGTCCTATTTGCTGCCCTT }\end{array}$ & Glu-By8 & 527 & $\begin{array}{l}\text { Lei et al. } \\
(2006)\end{array}$ \\
\hline $\begin{array}{l}\text { ZSBy9aF } \\
1 / R 3\end{array}$ & $\begin{array}{l}\text { F:TTCTCTGCATCAGTCAGGA } \\
\text { R:AGAGAAGCTGTGTAATGCC }\end{array}$ & Glu-By9 & $707 / 662$ & $\begin{array}{l}\text { Lei et al. } \\
(2006)\end{array}$ \\
\hline BxFp & $\begin{array}{l}\text { F: CGCAACAGCCAGGACAATT } \\
\text { R: AGAGTTCTATCACTGCCTGGT }\end{array}$ & Glu-Bx17 & 675 & $\begin{array}{l}\text { Ma et al. } \\
(2003)\end{array}$ \\
\hline Dx5 & $\begin{array}{l}\text { F: CGTCCCTATAAAAGCCTAGC } \\
\text { R: AGTATGAAACCTGCTGCGGAC }\end{array}$ & Glu-D1d & 450 & $\begin{array}{l}\text { Ma et al. } \\
\text { (2003) }\end{array}$ \\
\hline
\end{tabular}

\section{Results and Discussion}

Total protein content of the wheat genotypes studied varied between 11.08 and $13.7 \%$ (Table 2). Previous reports also showed that protein percentage among different Bangladeshi wheat varieties ranged between 11-14\% (Kamal et al. 2003, Alam 2012, Hakim et al. 2012). Protein percentage ranging from $12-14 \%$ in wheat flour is desirable for making bread. Generally harder the wheat, higher the protein content in the flour and hard wheat flours are suitable for making bread (North American Millers' Association 2018). Total protein content of more than half of the genotypes (54.54\%) ranged between $12-14 \%$ which is considered as a suitable range of protein for making bread.

Glutenin subunits having molecular weight of above $80 \mathrm{kDa}$ are considered as HMW-GSs (Bietz and Wall, 1972). The SDS-PAGE results from the present study showed that molecular weight of all the identified bands ranged from 85$135 \mathrm{kDa}$ (Fig. 1).

Three different types of Glu-A1 alleles were found in all 26 wheat genotypes: Ax1, Ax2* and the null allele. Ax2* was the most common allele found in almost $90 \%$ Bangladeshi wheat varieties and both of the Australian wheat varieties used in this experiment. In the Glu-1B locus, a total of four different alleles were found: Bx7, Bx7+By8, Bx7+By9 and Bx17+By18 (Table 3). Bx7 was a common 
allele found in $90.9 \%$ of all the genotypes. In three genotypes (Lane 1, 3 and 5; Fig. 1), presence of both Bx7 and Bx17+By18 alleles were seen in SDS-PAGE. In Glu-1D loci three types of alleles were found: Dx5+Dy10, Dx12, Dx2+Dy12 (Table 3). Dx5+Dy10 and Dy12 alleles were found in 61.54 and 38.46\% of the genotypes, respectively. Only one Bangladeshi wheat variety (BARI Gom 25) showed the presence of Dx2+Dy12 allele.

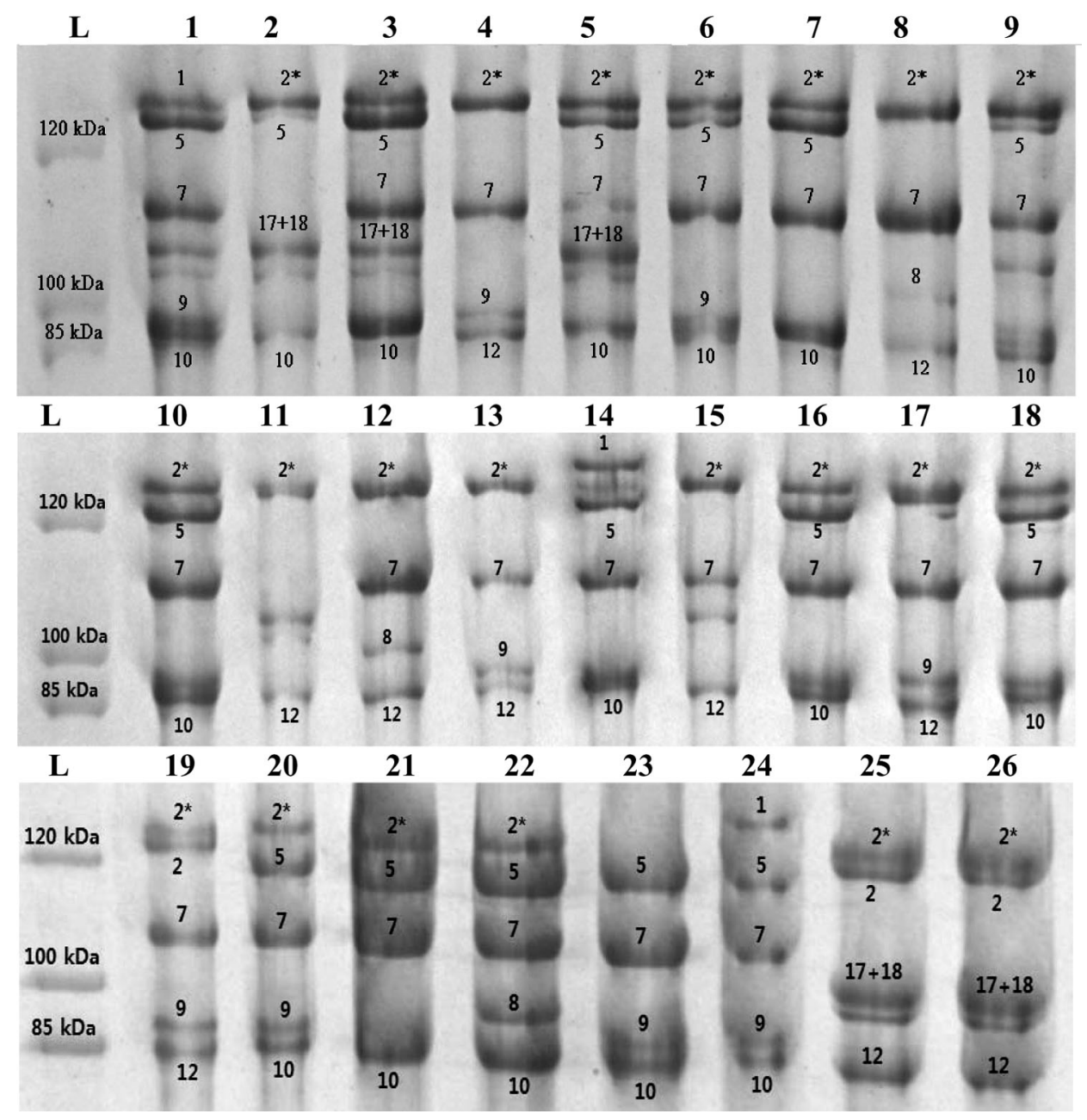

Fig. 1. SDS-PAGE of major allelic forms of HMW subunits present in wheat genotypes 1-26. [1 = Kheri; 2 = Kalyansona; 3 = Sonora-64; 4 = Sonalika; $5=$ Pavon-76; 6 = Balaka; 7 = Ananda; 8 = Kanchan; 9 = Akbar; $10=$ Barkat; $11=$ Aghrani;12 = Protiva; $13=$ Sourav; $14=$ Gaurav; $15=$ Shatabdi; 16 = Sufi; 17 = Bijoy; 18 = Prodip; $19=$ BARI Gom 25; $20=$ BARI Gom 26; 21 = BARI Gom 27; 22 = BARI Gom 28; 23 = Mulika; 24 = Paragon; 25 = Westonia 5907; 26 = Westonia 5924] . 
Table 2. Total protein percentage of the wheat genotypes under study.

\begin{tabular}{|c|c|c|c|}
\hline $\begin{array}{l}\text { Name of the } \\
\text { varieties and lines }\end{array}$ & $\begin{array}{c}\text { Protein } \\
(\%)\end{array}$ & $\begin{array}{l}\text { Name of the } \\
\text { varieties and lines }\end{array}$ & $\begin{array}{c}\text { Protein } \\
(\%)\end{array}$ \\
\hline 1. Kheri & 12.24 & Gaurav & 12.24 \\
\hline 2. Kalyansona & 11.89 & Shatabdi & 11.43 \\
\hline 3. Sonora- 64 & 11.25 & Sufi & 13.06 \\
\hline 4. Sonalika & 13.06 & Bijoy & 12.24 \\
\hline 5. Pavon- 76 & 11.25 & Prodip & 12.71 \\
\hline 6. Balaka & 11.43 & BARI Gom 25 & 13.53 \\
\hline 7. Ananda & 11.89 & BARI Gom 26 & 11.08 \\
\hline 8. Kanchan & 12.24 & BARI Gom 27 & 11.75 \\
\hline 9. Akbar & 13.06 & BARI Gom 28 & 11.75 \\
\hline 10. Barkat & 12.42 & Mulika & 9.97 \\
\hline 11. Aghrani & 12.24 & Paragon & 14.69 \\
\hline 12. Protiva & 11.89 & Westonia 5907 & 11.25 \\
\hline 13. Sourav & 13.70 & Westonia 5924 & 12.42 \\
\hline
\end{tabular}

PCR test results showed that $\mathrm{Ax} 2^{*}$ and $\mathrm{Bx} 7$ alleles were present in $84.62 \%$ and $84.62 \%$ of the genotypes studied which is nearly matched the results obtained by SDS-PAGE analysis. Although the presence of By8 and By9 alleles were observed in SDS-PAGE, no bands were obtained by PCR using By8 and By9 specific primers. Bx17 specific primers amplified the expected band from five genotypes. PCR test was done to confirm the presence of Bx7 and Bx17+18 alleles in same varieties. Two genotypes (Sonora-64 and Pavon-76) showed amplification for both Bx7 and Bx17+By18 in PCR (Fig. 2C, D, lane 3 and 5). Presence of the Dx5 allele was found in $61.54 \%$ of the genotypes evaluated which is consistent with the results obtained from the SDS-PAGE analysis except for 2 genotypes, Balaka and Kanchan (Figs 1 and 2E, lane 6 and 8).

In SDS-PAGE, Ax1 allele in 'Kheri' (Fig. 1; lane 1) looks different than the Ax1 allele found in Gaurav and Paragon (Fig. 1; lane 14 and 24), but repeated PCR analyses with Ax1 specific primers showed positive results confirming the presence of Ax1 allele in Kheri. In Mulika in SDS-PAGE no allele was found in "A" locus (null allele) (Fig. 1; lane 23) but later PCR analysis showed positive result for Ax1 allele (Fig. 3; lane 23). This might happen when the gene is present but not expressed into a protein. Presence of $A x 2^{*}$ in the combination with Dx5+Dy10 are normally associated with superior bread quality (Payne et al. 1987, Dong et al. 2009). Almost half (46.15\%) of the wheat genotypes from the present study have this combination and can be considered as suitable for making good quality bread. These genotypes can also be used in breeding programmes for incorporating any of these alleles into new wheat varieties. 


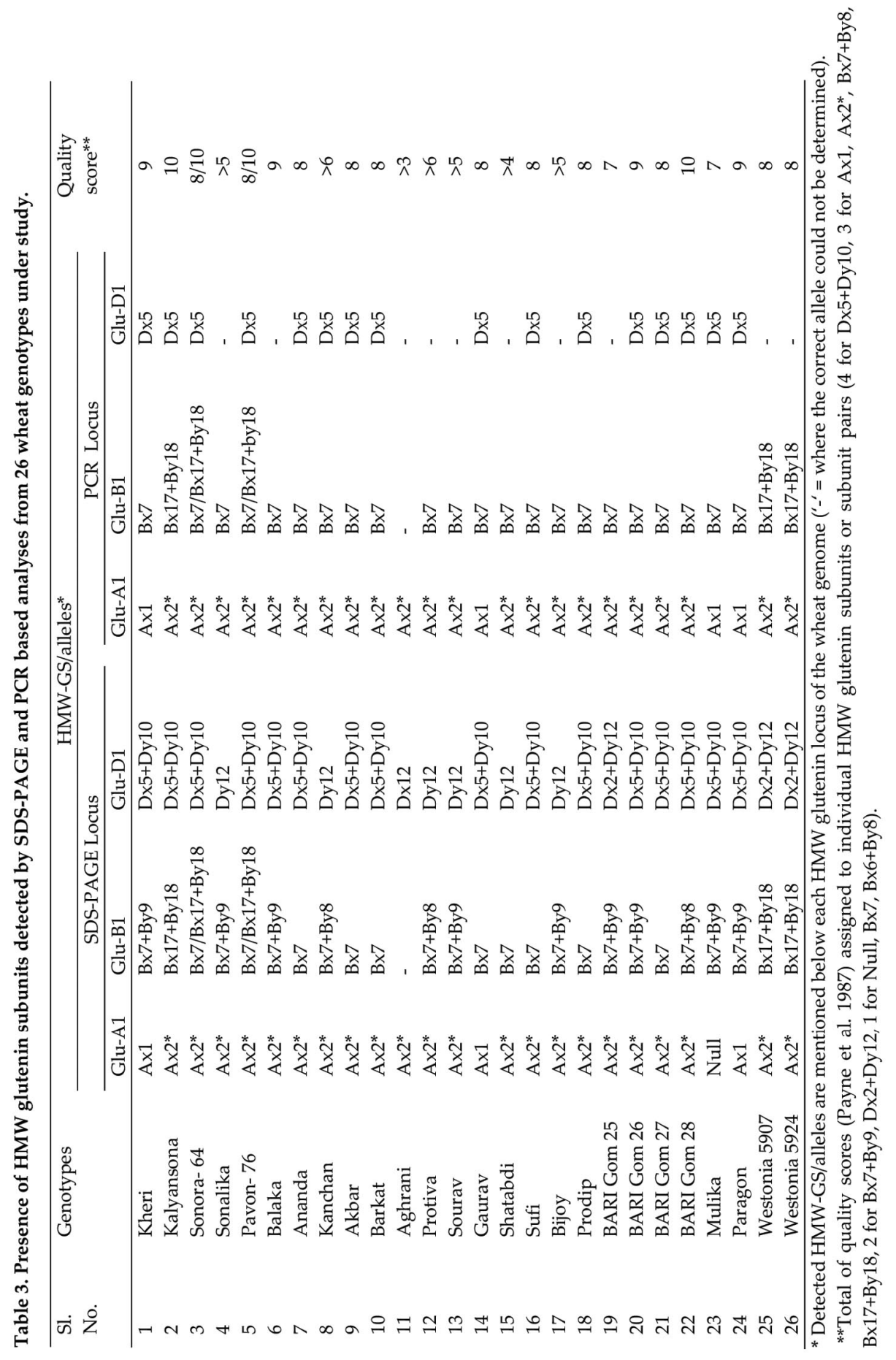




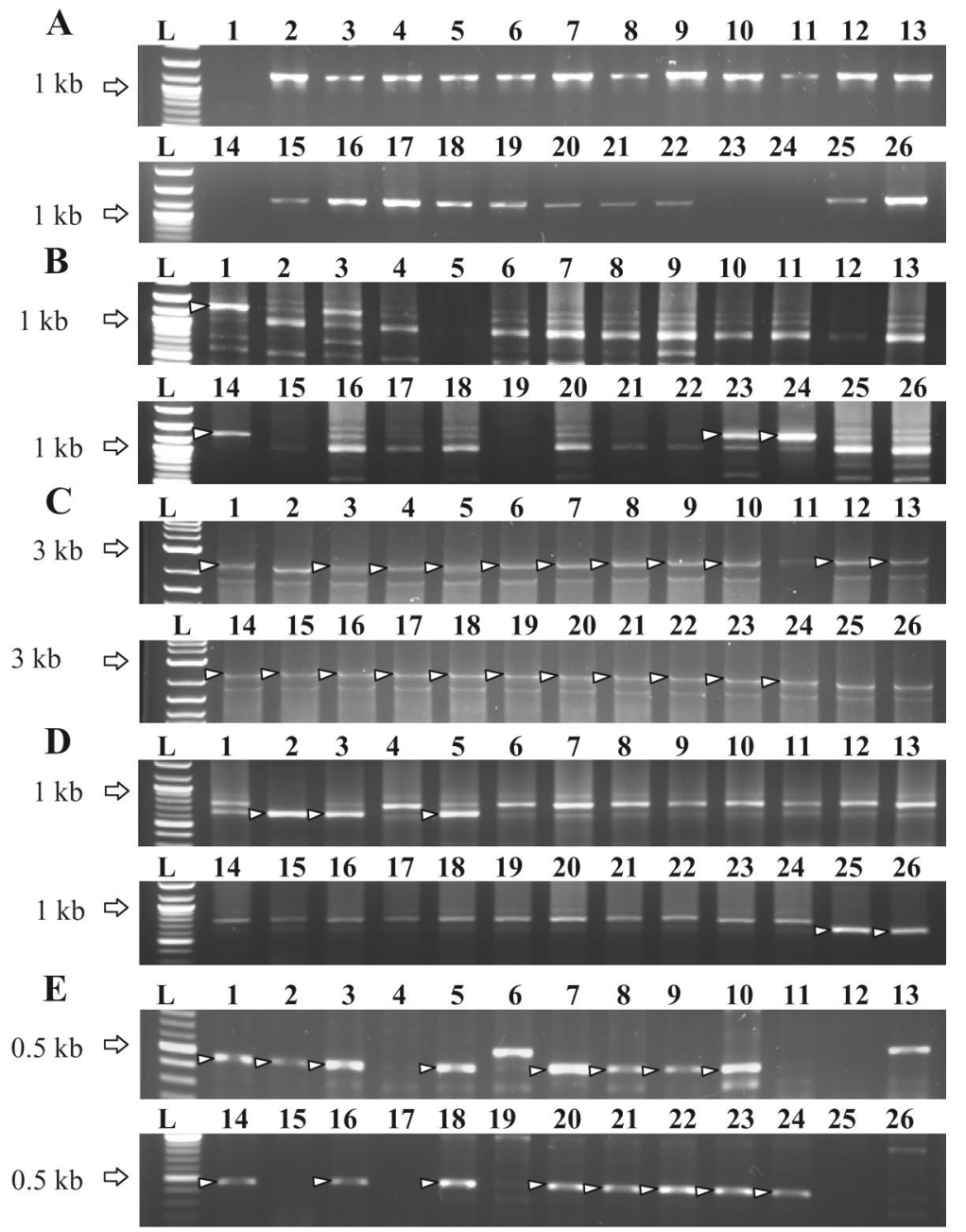

Fig. 2.PCR amplification of different HMW-GS alleles from 26 wheat genotypes. (A) Ax2* allele; (B) Ax1 allele; (C) Bx7 allele; (D) Bx17 allele and (E) Dx5 allele [Bands for the respective alleles are arrowed where applicable; lanes $1=$ Kheri; 2=Kalyansona; 3=Sonora- 64; 4=Sonalika; 5=Pavon76; 6=Balaka; 7=Ananda; 8=Kanchan; 9=Akbar; 10=Barkat; 11=Aghrani;12=Protiva; 13=Sourav; 14=Gaurav; 15=Shatabdi; 16=Sufi; 17=Bijoy; 18=Prodip; 19=BARI Gom25; 20=BARI Gom 26; 21=BARI Gom 27; 22=BARI Gom 28; 23=Mulika; 24=Paragon; 25=Westonia 5907; 26=Westonia 5924; $\mathrm{L}=$ DNA ladder].

Marchylo et al. 1992 and Butow et al. 2003 stated that Bx7 enhanced dough quality, although quality score of Bx7 is very low (1) according to (Payne et al. 1987). Most of the (94.44\%) Bangladeshi genotypes possess Bx7 allele that can contribute in enhancing dough quality. Presence of allelic pair Bx17+By18 in wheat varieties has also been reported to be good for bread-making quality $(\mathrm{Xu}$ 
et al. 2008, Dong et al. 2009, Liang et al. 2010) having a high quality score 3 (Payne et al. 1987). Kalyansona, Sonora-64, Pavon-76, Westonia-5907 and Westonia 5924 having the above allelic combination could be considered as good bread-making wheat genotypes. However, Sonora-64 and Pavon-76 showed presence of both for Bx7 and Bx17+By18 alleles both in SDS-PAGE and PCR analysis (Table 3).

The Glu-D1 locus has the largest effect on bread-making quality (Krystkowiak et al. 2017). The combination of Dx5 with Dy10 is associated with good bread quality (Payne et al. 1981, Payne et al. 1987, Popineau et al. 1994, Cong et al. 2007) and the quality score for this allele is 4, which is the highest score among all the HMW-GSs (Payne et al. 1987). Therefore, $61.54 \%$ of the genotypes evaluated in the present experiment having Dx5+Dy10 allelic pairs could be considered of very good bread-making quality. On the other hand, allelic pair Dx2+Dy12 is associated with poor bread quality and has been assigned low quality score (2). Only BARI Gom 25 a Bangladeshi wheat variety showed positive result for Dx2+Dy12. However, in 'A' locus, Ax2* allele has been found in this variety which is usually associated with high bread-making quality. Further bread baking tests might be able to show actual quality status of this variety.

Thirteen different allelic combinations were detected in the present study with a total of 14 Glu- 1 loci. The most common allelic combination $\left(2^{*}, 7\right.$ and $5+10$ ) was found in $23.08 \%$ of the genotypes. Both Ax2*, Bx17+By18, Dx5+Dy10 and $\mathrm{Ax} 2^{*}, \mathrm{Bx} 7+\mathrm{By} 9, \mathrm{Dy} 12$ were the second most frequent allelic combinations and were detected in $11.54 \%$ of the genotypes. The overall quality scores displayed a range from $>3$ to 10 , however generally good quality score of eight was more frequent (42.31). The highest quality scores of 10 and 9 were observed in 15.38 and $15.38 \%$ of the genotypes, respectively. Both Sonora-64 and Pavon-76 have been scored 8 and 10 since both of them showed presence of Bx7 and Bx17+By18 alleles in SDS-PAGE and PCR. Kalyansona and BARI Gom 28 had the highest quality score 10 and the best HMW-GS combination of Ax2*, Bx17+By18, Dx5+Dy10 and Ax2*, Bx7+By8, Dx5+Dy10, respectively (Table 3). However, in PCR no result was obtained for By8 and By9.

On the basis of allelic compositions and gluten quality scores assigned according to Payne et al. (1987), one Bangladeshi variety BARI Gom 28 has very good bread-making alleles and can be used for producing high quality bread. Other Bangladeshi wheat genotypes e.g., Balaka, Ananda, Akbar, Barkat, Gaurav, Sufi, Prodip, BARI Gom 26 and BARI Gom 27 are also of good breadmaking quality as these varieties have important bread quality determining alleles: Ax1, Ax2* and Dx5+Dy10, thereby their greater utility in bread-making 
quality improvement breeding is suggested. Results presented here are based on laboratory analyses of protein and DNA markers only. Further investigation by rheological studies of the dough properties and actual baking experiments will help to confirm the findings of this study.

\section{Acknowledgement}

This work was carried out at the Biotechnology Division, Bangladesh Agricultural Research Institute (BARI) as a part of Master program in Biochemistry of the corresponding author at Sher-e-Bangla Agricultural University, Dhaka, Bangladesh. Authors would like to thank Dr. Ashrafi Hossain, Associate Professor, Sher-e-Bangla Agricultural University, Dhaka, Bangladesh for her support during the course of the study.

\section{Reference}

Ahmad M (2000) Molecular marker-assisted selection of HMW glutenin alleles related to wheat bread quality by PCR-generated DNA markers. Theor. Appl. Genet. 101: 892896.

Alam MS (2012) Effect of sowing patterns and nitrogen rates on quality traits and yield of wheat. J. Environ. Sci. \& Natural Resources 5: 267-272.

Anderson DD and Greene FC (1989) The characterization and comparative analysis of high-molecular-weight glutenin genes from genomes A and B of a hexaploid breadwheat. Theor. Appl. Genet. 77: 689-700.

Bietz JA and Wall JS (1972) Wheat gluten subunits: Molecular weights determined by sodium sulfate-polyacrylamide gel electrophoresis. Cereal. Chem. 49: 416-430.

Butow BJ, Ma W, Gale KR, Cornish GB, Rampling L, Larroque O, Morell MK and Bekes F (2003) Molecular discrimination of Bx7 alleles demonstrates that a highly expressed high-molecular-weight glutenin allele has a major impact on wheat flour dough strength. Theor. Appl. Genet. 107: 1524 -1532.

Cong H, Takata K, Ikeda TM, Yanaka M, Fujimaki $\mathbf{H}$ and Nagamine T (2007) Characterization of novel high-molecular-weight glutenin subunit pair $2.6+12$ in common wheat landraces in the Xinjiang Uygur autonomous districts of China. Breed. Sci. 57: 253-255.

Dewettinck K, Van Bockstaele F, Kühne B, Van de Walle D, Courtens TM and Gellynck X (2008) Nutritional value of bread: Influence of processing, food interaction and consumer perception. J. Cereal. Sci. 48: 243-257.

Dong K, Hao CY, Wang AL, Cai MH and Yan YM (2009) Characterization of HMW glutenin subunits in bread and tetraploid wheats by reversed-phase highperformance liquid chromatography. Cereal Res. Commun. 37: 65-72.

Dubcovsky J, Tranguilli G, Lizavetzky D, Khan IA, Schlatter AR, Manifesto MM and Marcucci-Poltri S (1998) Advance molecular markers for bred making quality. 
International Workshop Application of Biotechnology in wheat Breeding, Colonia, Urugua. Nov. 19-20, 1998. pp. 57-70.

Goesaert H, Brijs K, Veraverbeke WS, Courtin CM, Gebruers K and Delcour JA (2005) Wheat flour constituents: How they impact bread quality, and how to impact their functionality. Trends Food. Sci. Technol. 16: 12-30.

Gupta RB, Masci S, Lafiandra D, Bariana HS and MacRitchie F (1996) Accumulation of protein subunits and their polymers in developing grains of hexaploid wheats. J. Exp. Bot. 47: 1377-1385.

Hamer RJ, Weegels WP and Marseille JP (1992) Prediction of breadmaking quality of wheat: The use of HMW glutenin A subunit based quality scoring systems. J. Cereal. Sci. 15: 91-102.

Hossain A and Teixeira da Silva JA (2013) Wheat production in Bangladesh: its future in the light of global warming. AoB Plants 5: pls042..

Hakim MA, Hossain A, Teixeira da Silva JA, Zvolinsky VP and Khan MM (2012) Yield, protein and starch content of twenty wheat (Triticum aestivum L.) genotypes exposed to high temperature under late sowing conditions. J. Sci. Ind. Res. 4: 477-489.

International Development Research Centre (2010) Facts and Figures on Food and Biodiversity, https://www.idrc.ca/en/article/facts-figures-food-and-biodiversity Accessed on 2 June 2018.

Kamal AMA, Islam MR, Chowdhury BLD and Talukder MAM (2003) Yield Performance and Grain Quality of Wheat Varieties Grown under Rainfed and Irrigated Conditions. Asian J. Plant Sci. Res. 2: 358-360.

Krystkowiak K, Langner M, Adamski T, Salmanowicz BP, Kaczmarek Z, Krajewski P, Surma M (2017). Interactions between Glu-1 and Glu-3 loci and associations of selected molecular markers with quality traits in winter wheat (Triticum Aestivum L.) DH Lines. J. Appl. Genet. 58: 37-48.

Lei ZS, Gale KR, He ZH, Gianibelli C, Larroque O, Xia XC, Butow BJ and Ma W (2006) Y-type gene specific markers for enhanced discrimination of high-molecular weight glutenin alleles at the Glu-B1 locus in hexaploid wheat. J. Cereal Sci. 43: 94-101.

Liang D, Tang J, Peña RJ, Singh R, He X, Shen X, Yao D, Xia X and He Z (2010) Characterization of CIMMYT bread wheats for high and low-molecular weight glutenin subunits and other quality-related genes with SDS-PAGE, RP-HPLC and molecular markers. Euphytica 172: 235-250.

Malik AH (2009). Nutrient uptake, transport and translocation in cereals: influences of environmental and farming conditions. Introductory Paper at the Faculty of Landscape Planning. Horticulture and Agricultural Science (1654-3580), pp 1-46.

Marchylo BA, Lukow OM and Kruger JE (1992) Quantitative variation in high molecular weight glutenin subunit 7 in some Canadian wheats. J. Cereal Sci. 15: 29-37.

Morel M and Bar-L'Helgouac'H C (2000) Reliable estimates of gliadin, total and unextractable glutenin polymers and total protein content from single SE-HPLC analysis of total wheat flour protein extract. In: Shewry, P.R. and Tatham, A.S. (eds) Wheat Gluten. UK, The Royal Society of Chemistry pp. 140-143. 
Ma W, Zhang W and Gale KR (2003) Multiplex-PCR typing of high molecular weight glutenin alleles in wheat. Euphytica 134: 51-60.

North America Millers' Association (2016) Types of Flour http://www.namamillers.org /education/types-of-flour/Accessed on 02 June 2018.

Payne PI, Corfield KG, Holt LM and Blackman JA (1981) Correlation between the inheritance of certain high-molecular-weight subunits of glutenin and bread-making quality in progenies of six crosses of bread wheat. J. Sci. Food Agric. 32: 51-60.

Payne PI, Nightingale MA, Krattiger AF and Holt LM (1987) The relationship between HMW glutenin subunits composition and bread-making quality of British grown wheat varieties. J. Sci. Food Agric. 40: 51-65.

Popineau Y, Cornec M, Lefebvre J and Marchylo B (1994) Influence of high Mr glutenin subunits on glutenin polymers and rheological properties of glutens and gluten subfractions of near-isogenic lines of wheat. Sicco. J. Cereal Sci. 19: 231-241.

Xu Q, Xu J, Liu CL, Chang C, Wang CP, You MS, Li BY and Liu GT (2008) PCR-based markers for identification of HMW-GS at Glu-B1x loci in common wheat. J. Cereal Sci. 47: 394-398. 